\title{
Histotoxin の知見補遺
}

\author{
其二 紫外線照射に因るHistotoxinの \\ 產成飞就て \\ 中 橋 幸馬
}

(京城帝國大學醫學部藥理學教室 [大澤 呚授〕)

(昭和十七年六月二十九日受付)

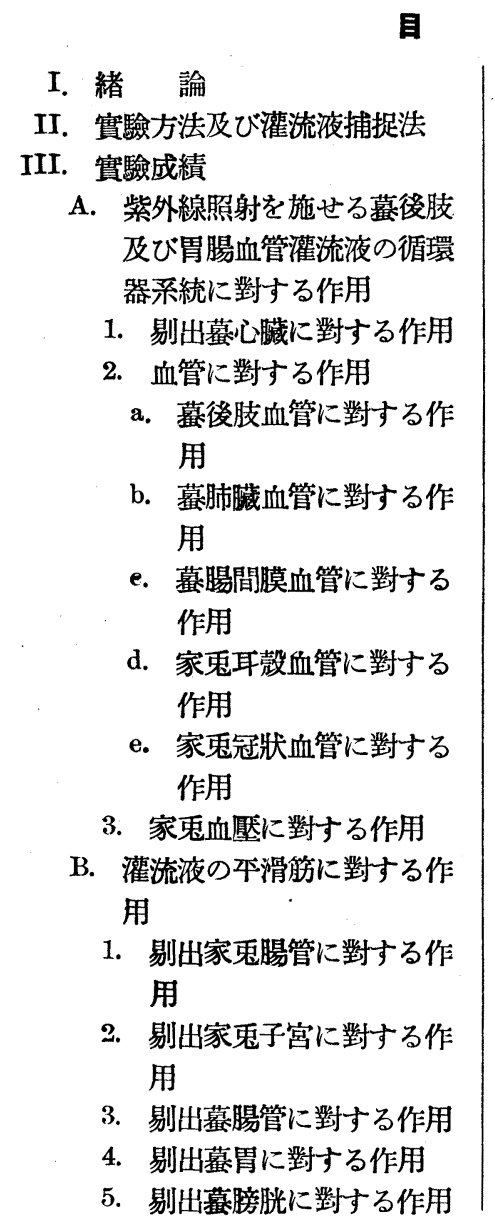

次

6. 體內蟇膀胱に對する作 用

C. 灌流液の蛬腓腸筋灌流梅本 の收縮高に及ぼす影響

D. 灌流液の鹳腎贜血管及び腎 分泌に及ぼす影響

E. 種々なる要約の下に於ける 灌流夜の能動性の變化
1. 室溫放置
2. 加 熱
3. 吸 着
4.1 紫外線照射
5. 透析 性
6. 灌流液の二, 三物理化學 的性狀に就て

IV. Histamin との異同

V. Histotoxin との關係

VI. 家鬼血液像に對する作用
A. 灌流液の家鬼血液像に及ぼ 寸影響
B. 紫外線照射を施せる家束血 液像
C. 本編の考案

VII. 總括考案並に結論
1. 總括及び考案
2. 結 論
引用書目 


\section{I. 緒論}

日光療法の效果は今や一般の認むる所となり，各種の奖病治療に應用せらるっに至れ り. 而して該療法の臹治的效果は主として太陽光線中の紫外線の作用に歸せざる可からず. 從つて紫外線に對する認識頓に揚り研究相踵んで盛となれり。されば治療學的及び生物學 的方面の研究業績に於ても亦甚だ多し. 試みに之が二三摘錄すれば, 即ち.1904 年 Hertel ${ }^{1}$ ) は紫外線を海膽卵に照射し細胞體の分裂が阻害せらる」を認め, Schleip ${ }^{2}$ )は細胞の原形筫 及び核に別個に影響を與ふるを明にして興味ある研究を發表せり.

小野 ${ }^{3}$ ) 注家鬼新鮮血液の叙抹標本に紫外線に富める人工太陽燈を照射し，白血球に强 力なる障害を及ばすを證明せり，Gassub $\left.{ }^{4}\right), S a c k{ }^{5}$ ) はしマウスา 亿人工太陽燈を照射し內臟に 火傷時之同樣の充血及び圆形細胞の浸潤あるを明にし; Nathan ${ }^{6}$ ), Sack ${ }^{7}$ ) は照射並に非照 射皮虐の抽出液を正常海猽皮內に注射し，照射皮膚の抽出液に著明なる炎泟を若起する作 用ある觀，光線皮膚炎の或部分は間接作用に因るものなり之唱へたり.更飞 Trendelenburg ${ }^{8}$ ), Ellinger ${ }^{9}$ ) は紫外線照射部の皮膚に全身作用を來す物質を證明し，該物質は Histamin なり と發表せり。本邦に於ては㞸永 ${ }^{10}$ ), 竹林 ${ }^{\left.{ }^{\prime}\right)}$ 泣紫外線照射により 組織中の Histamin の增加 せるを明にし，松下 ${ }^{12}$ ) も亦家鬼に紫外線を照射し，皮膚に Histamin の座成さる〉を實驗 的に證明せり. 西 ${ }^{13}$ ) 亦同樣にして血山の Histamin の增加之殘餘窒素の增加せるを認めた

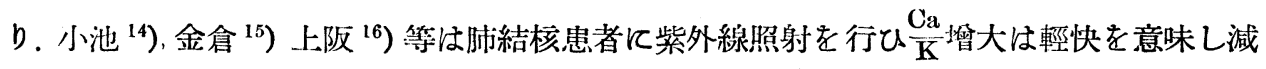
少は反對の絬果を示すと謂へり。大里 ${ }^{17}$ ), 田中 ${ }^{18}$ ) 等は貧血狀態に於ける動物の血液再生が 紫外線にて增强せらる〉を明にし，Seyderhelm ${ }^{19}$ ) は抗貧血性物質の血中に 增加せらるを貫 驗的に證明せり.1923 年 Hess ${ }^{20}$ )，Weinstock ${ }^{21}$ ) は紫外線照射を施したる食物に 抗何僂病作 用あるを觀，亦 Windaus ${ }^{22}$ ) Hess と共に Ergosterin が照射に低り抗佝僂病性となる物質 なるを明にして佝僂病治療に對して, 紫外線の有效なるを提唱せり。柴外線は又結核及び其 他皮膚疾患等の治療伤盛飞應用せらる.Sorgo ${ }^{23}$ ) は其の作用機轉に 關し照射部の皮膚及び 冈部の淋巴流の旺盛を以て說明せんとし, Bernhard $\left.{ }^{24}\right)$, .Hausmann ${ }^{25}$ ) 等はSorgo の說に實驗 的根據を與へたり。即ちSorgo 其他の人々は火傷部に生じをる蛋白分解產物の 全身, 並に 內部贜器に及ぼす作用の類推に依り之を證明せんと企てたり。本澤 ${ }^{26}$ ), 真野 ${ }^{27}$ ) 等は彼等の 浩瀚なる結核に對する實驗的研究よりしで, 紫外線は值接深部組織に對し作用を及ばすも のにあ,らすして皮膚に與へたる刺钱により，治療に導くるのなれば光線療法は廣義の刺㦸 療法なりと結論せり。

以上の研究の跡を觀るに其の成績必ずしも一致すと謂ふを得さるも，紫外線照射が一 定の治療的意義を有し，而子其の照射局所に於て能動性物質の座生を見るは略々一般に認 
338

中橋幸馬：

められたる處なるも該物質の本態は，岩永等の唱ふるが如き Histamin なるや，或は本物質 が紫外線照射の時に見らる〉種々なる定狀の出現に對し, 又治療作用に對し如何なる 意義 を有するか猶不明なる點多し。既に本呚室に於て劉 ${ }^{28}$ )は Röntgen-線照射部位に 能動性物 質の㡾成せらる」を實驗的に明にし, 而も本物質は三浦 ${ }^{29}$ ), 安野 ${ }^{30}$ ), 嶋田 ${ }^{31}$ ) 等が化學的或 は物理學的方法により障碍を與へたる組織より登明せる Histotoxin と相一致するを以て Röntgen 線の如き光線療法は一の非特異性刺钱療法乙して役立つものなるを提唱せる事貝 と合せ考へ, 余も亦藥理學的立場より紫外線作用の探究を志し二, 三の事埥を得たるを以 て略述し，紫外線作用の知見に對し追補する所あらんとす.

\section{II. 賈驗方法及び濩流液捕捉法}

實驗動物は實驗條件を簡易ならしむる䉆めに慕を選び $200 \mathrm{~g}$ 內外の內地産及び朝鮮虖のものを使用 し, 灌流液捕集には後述の 3 方法を探用せり .

1). Laewen-Trendelenburg-法により䒱後肢血管灌流標本を作製し，Ringer-液を以て灌流し，その静 脈 レカニューレフより流出する灌流液が Sulfosalicyl-酸による蛋白反㕍が全く陰性となるに及び, 其灌 流液を探集し是を對照實驗に用ひ, 然る後灌流を停止し紫外線照射を行ひたり.

照 射 方 法

發生裝置 島津製鑑識用紫外線 レランプフ (“Acme,, Analytische Lampe, Type A. Volt 100. M. A. 6 . 波長 $316-360$ 粍).

$\begin{array}{ll}\text { 照射距離 } & 20 \mathrm{~cm} \\ \text { 照射時間 } & 5^{\mathrm{m}} \text { 乃至 } 30^{\mathrm{m}} \text { 間 } \\ \text { 照射回數 } & 1 \text { 回 } \\ \text { 照射部位 } & \text { 下腹部及び後肢腹側面の皮膚 }\end{array}$

照射完了後再び灌流を行ひ，血管內に残存するRinger-液か照射時の灌流液に混入するを涺くる篇 め, 最初の約 $15 \mathrm{cc}$ を捨て其後の液を捕集し實驗に供せり.

2). 蟇の腹部及び後肢腹側面の皮虐に紫外線を照射し 種々の時期に於て 其の㱳の斷頭脊髓破壞を 行ひ, 然る後 Laewen-Trendelenburg-法により筃後肢血管灌流標本を作製し，Ringer-液を以て灌流し灌 流液が Sulfosalicyl-酸にて蛋白反應が全く陰性となるに至り灌流液を捕集し筫驗に使用せり.

照 射 方 法 發生裝置照射時間及び同距離Ｉ）の場合に同じ

照射回數 $\quad 1-3$ 回

照射完了より灌流時迄の經過時間。 $30 \mathrm{~m}$ 乃至 10 日間

3). 䓨の腹部及び後肢腹側面の皮虐に紫外線を照射し 種々の時期に於て斷頭脊髓を破㐭後之を背 位に固定し，然る後に胸腹部を開き胃腸血管へ滇流裝置を作製しRinger-液を以て灌流し其の靜胍 しカ ニニーレフより流出する液が Sulfosalicyl 酸にて蛋白反應全く陰性となるに及び, 灌流夜を捕集し 實驗 に用ひたり。

照射方法及び其他の條件 2) の場合と同じ 


\section{III. 實 驗 成，綪}

\section{A：紫外線照射を施せる蟇後肢及び胃腸血管擎流涴つ循環器系統に對する作用}

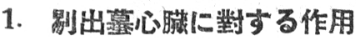

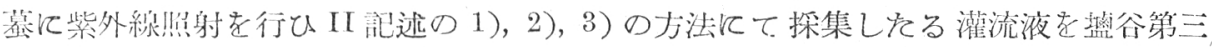

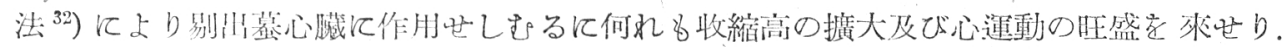

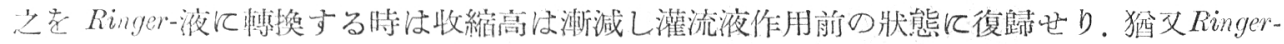
液を以て缚換吖ざるも時間の經過と共に漸次收縮高は舊狀に復するに至る。而して之等の 灌流液棌集方江，照射時間，同回數及び探集時期に低り剔出心臟飞對する作用に多少の

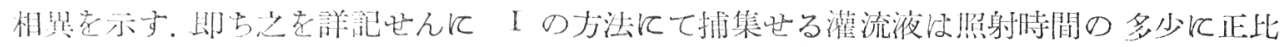

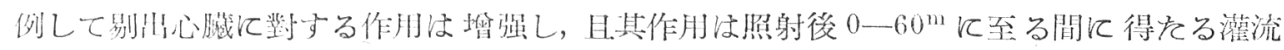

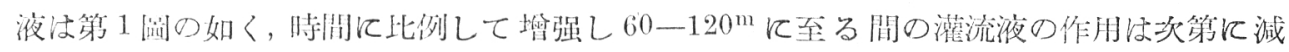

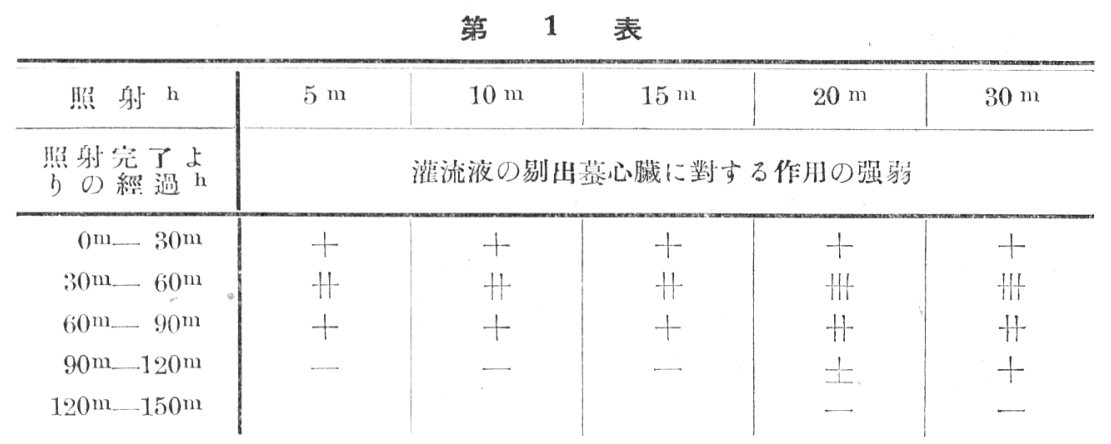

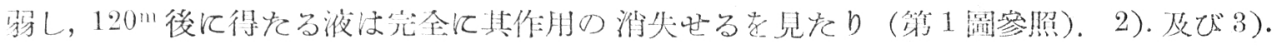

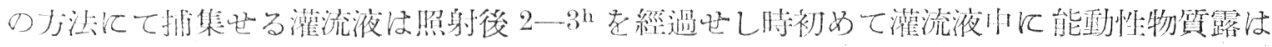
れ心㬴促進俳走示艺り。

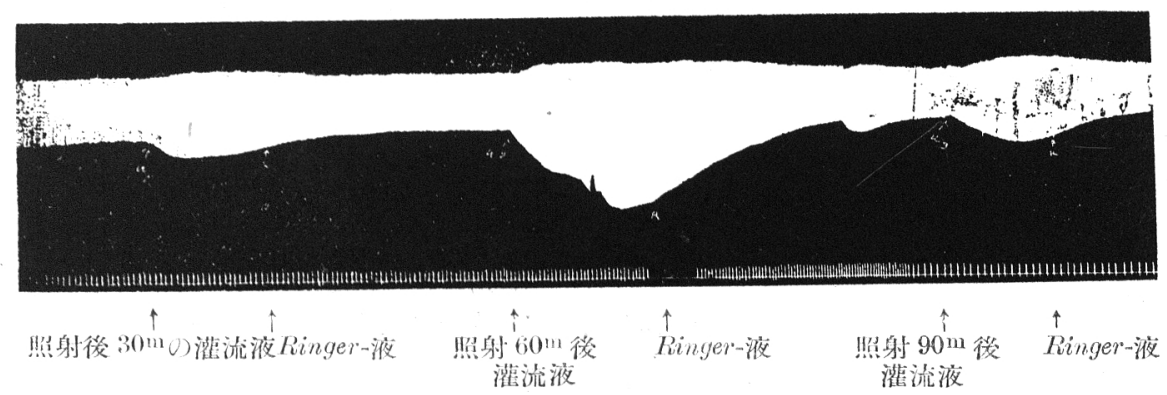

第 1 圖. （塔谷第三法） 
其作用は照射回數に比例して增强し，照射後 2 - 5 日を經過し灌流して得をる液に，最

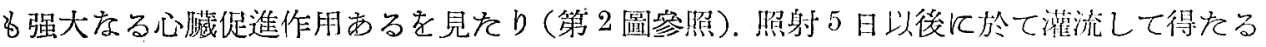

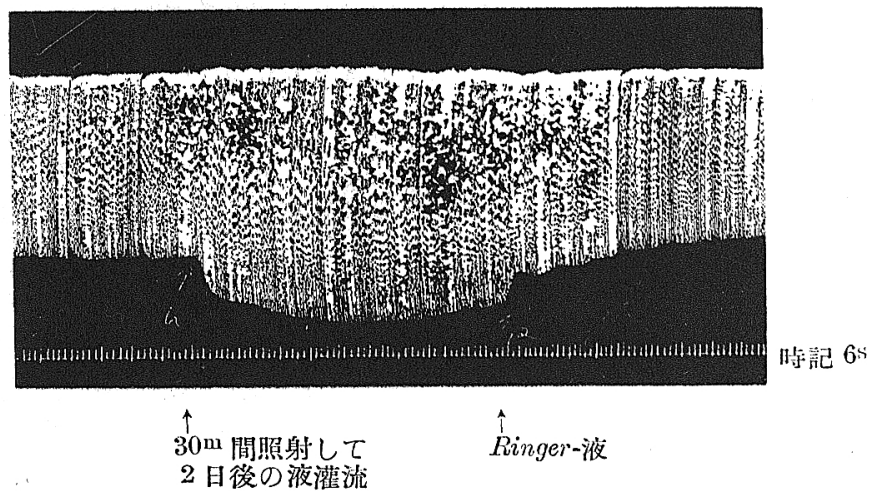

第 2 圖. (盐谷第 3 法)

液は日數の增加と共に其の作用は減少し，10昍を經過し灌流を行ひ得をる液は，能刺性物

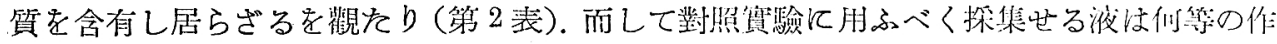
用をも示さざるを知れり。

\begin{tabular}{|c|c|c|c|c|c|}
\hline 照 射 $\mathrm{h}$ & $5 \mathrm{nx}$ & $10 \mathrm{~m}$ & $15 \mathrm{~m}$ & $20 \mathrm{~m}$ & $30 \mathrm{~m}$ \\
\hline $\begin{array}{l}\text { 照射上万灌流 } \\
\text { 洷る范の }\end{array}$ & \multicolumn{5}{|c|}{ 灌流液の剔出㟟心荗に對する作用の强弱 } \\
\hline $5 \mathrm{~h}$ & $H$ & H & $H$ & $H$ & $H$ \\
\hline $24 \mathrm{~h}$ & $H$ & H & $H$ & $11 t$ & $\| n_{11}$ \\
\hline 2 日 & + & H & 州舟 & 栦 & 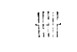 \\
\hline 3 日 & + & $H$ & H & Inlly & 桜 \\
\hline 5 日 & - & \pm & $H$ & $H+H$ & $H !$ \\
\hline 7 日 & & - & + & H & H \\
\hline 8 日 & & 。 & - & \pm & \pm \\
\hline $10 \mathrm{~B}$ & & & & - & - \\
\hline
\end{tabular}

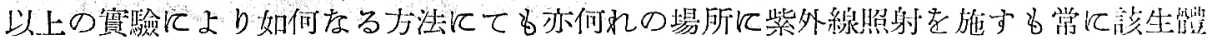

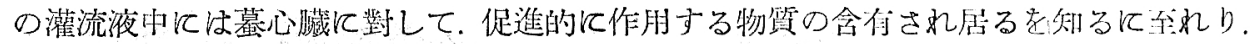

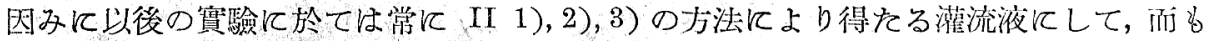
强大なる心臟促進作用を示寸液を用ひたり。

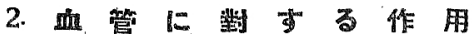

\section{a. 慕後肢盛管に對する作用}

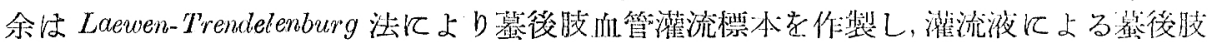


·血管の收縮或は擴張の狀況を觀んとし, 上田, 韓 ${ }^{33}$ )の改良せる大澤 ${ }^{34}$ ) 呚授匊泡描畫法に依 り其灌流 速度をしキモグラフィオンフの煤紙上に 畫かしめて檢せり. 施行せる 6 例は何れ b最初 Ringer-液を以て灌流し, 其の氣泡數の一定せる後之を藥理學的能動性物質含有の灌 流液に轉换するに氣泡數の減少を呈し，之を再び Ringer-液に換.るる時漸次復舊せり。然る に對照例に於てはかくの如き事なし. 是に依りて觀るに該灌流液は蟇後肢血管に對して收 縮的に作用するを知れり。

\section{b. 䀦䑏血管に新する作用}

斷頭脊㭪遀を破壞せる蟇を用ひ肺藏血管灌流標本を作製し，該灌流液を作用せしさるに 何れの例穴於ても著明なる收縮作用を招來せり（第 3 圖參照).

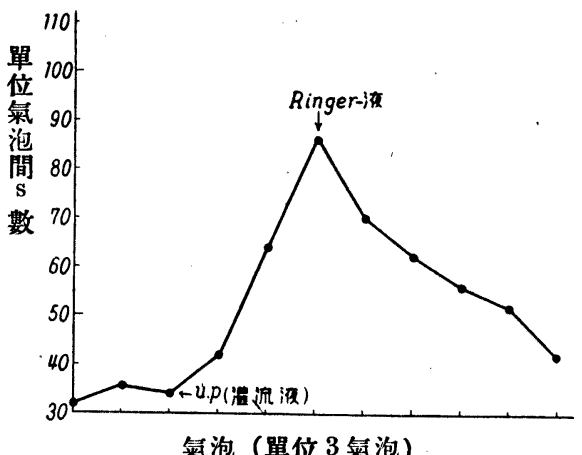

氣泡（單位 3 氣泡）

第3 回. 墓肺䐵血管。

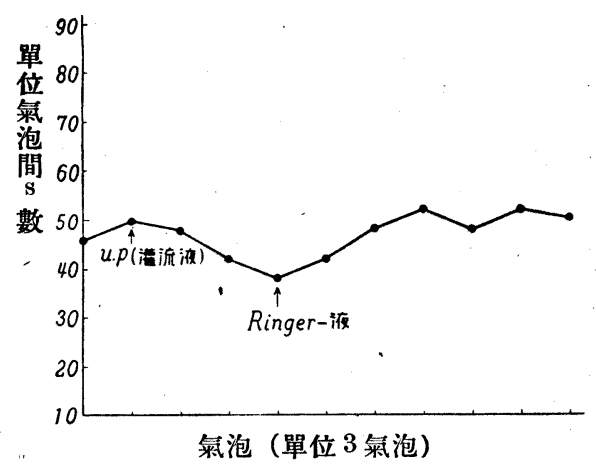

第 4 圆，蟇腸間膜血管.

\section{c. 基腸間膜血管に對する作用}

斷頭脊髓破壤後背位に固定し腹腔を開を蟇腸間膜血管灌流標本を作製し, 藥理學的能 動性物質を含有せる該灌流液を作用せしむるに，何れも氣泡の增加を來し、明に該液は蟇腸 間膜血管に曞張的に作用するを觀たり（第 4 圖參照）.

\section{d. 家鬼耳数血管に對する作用}

Krakow-Pissemski 法により家鬼耳款血管灌流標本を作製し, 本灌流液の家鬼耳款血管に 對する作用を檢せんとし，前記氣泡描畫法に依りキモグランイオン煤紙上に 灌流滴數を畫 かしめたり.該家鬼耳款血管は Locke-液を以て先づ灌流し氣泡の均定せる後灌流液を以て, 轉換すれば漸次氣泡數の減少を示し, 再び Locke-液に換ゆれば漸次舊に復せり. 即ち家鬼耳 款血管に對し該液は收縮的作用を示すを知れり。

\section{e. 家鬼冠狀血管に對する作用}

Langendorff 法て從ひ家鬼冠狀血管を肞ひ，該灌流液を家鬼冠狀血管に作用せしむるに 
蒙雸耳款血管と同樣の收絸作用を表はぜり。

\section{3. 家䨘盛壓に對する作用}

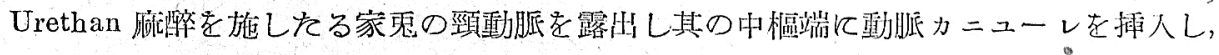

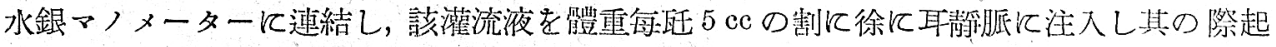

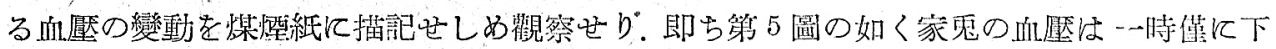
降するものの如し. 然るに對脰としてRinger一液を注入せば明に多少の上开を示せり。

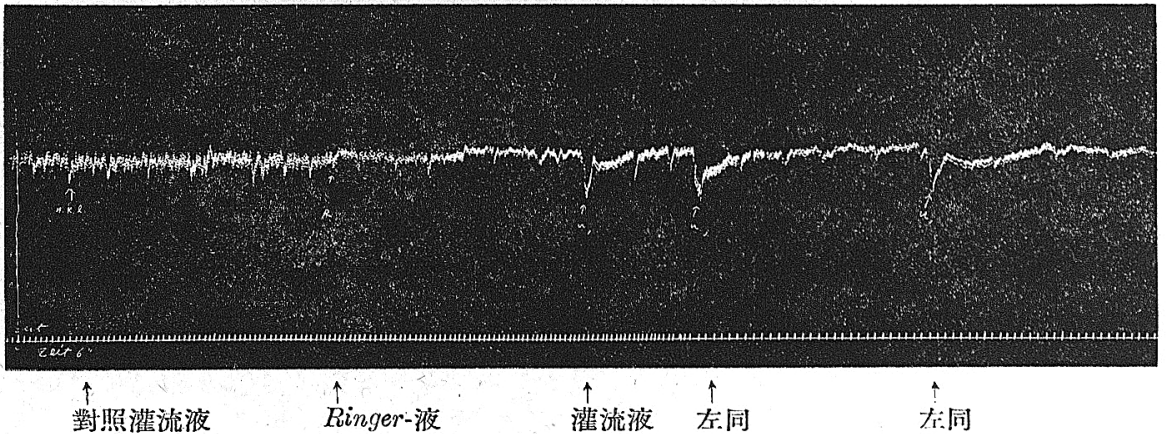

時剳 6 s

對照灌流液

第 5 圖. 家鬼血暨。

\section{B. 灌流液の平滑筋に對する作用}

\section{1. 㓭出家雨陽管に對する作用}

家亮剔出小腸片をMagnus-法により充分酸素にて 鉋和せるLocke-液中に䝮垂すれば整

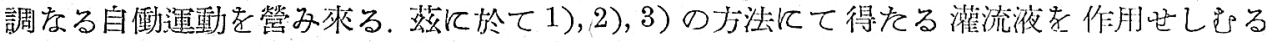
に全く無作用終れり。

\section{2. 剧出家忽子宮に對する作用}

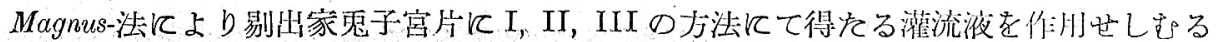
に, 何れの液も全く何等の變化をも招來せざりを.

\section{3. 㔀出莫腸䂏に對ずる作用}

1)，2，3）の方法にて得たる灌流液を以てMagnus-法により剔出䔄腸管に作用せしむる に，其の振幅を減し緊張下降を來せり，對照例に於ては全く何等の變動客も示さざるを觀 をり。

\section{4. 剔出葛腎に對する作用}

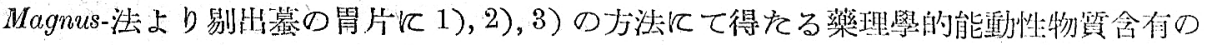


液を作朋せしさるる對照例之同樣全く何等の作用をも示さざるを知れり。

\section{5. 剔出遠膀胱に對する作用}

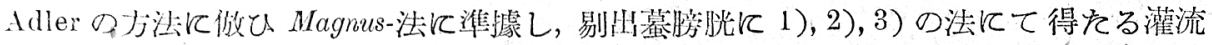
液を作朋せしさるに何れも强度の緊張上昇を示せり．然るに對照例に於ては何等の變化を

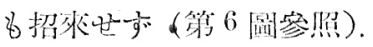

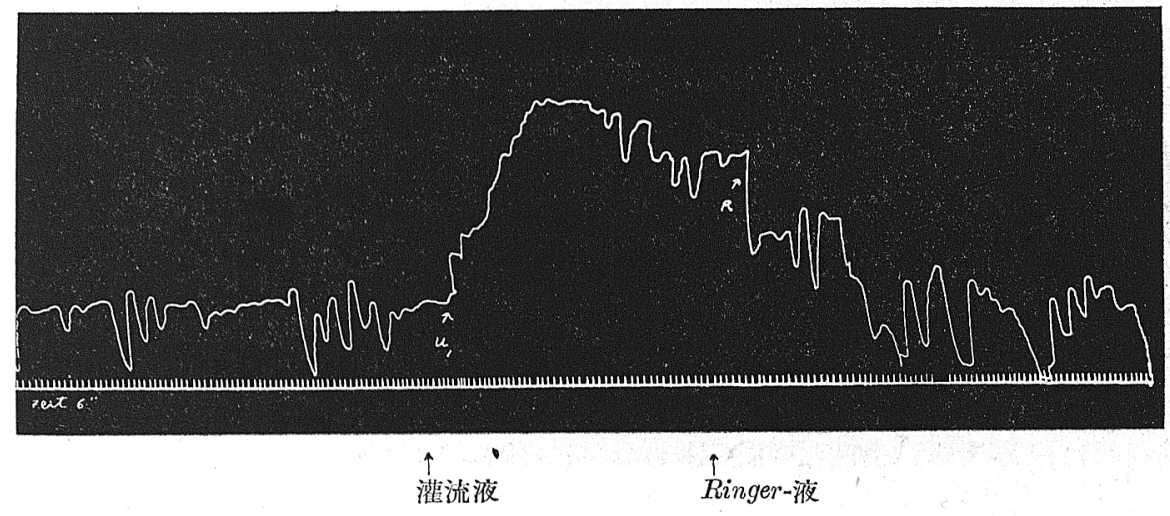

第 6 圖. 墓 膀 脱（剔出）(Magnus-法).

\section{6. 體內嵒膀胱に對する作用}

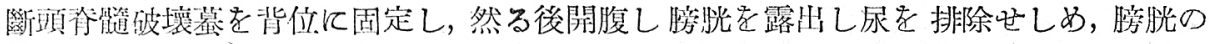

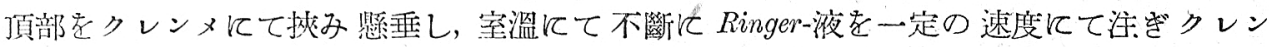

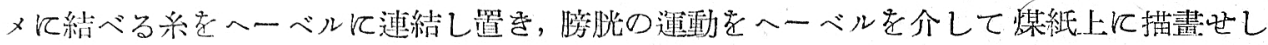

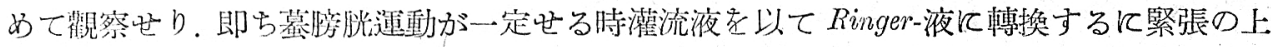

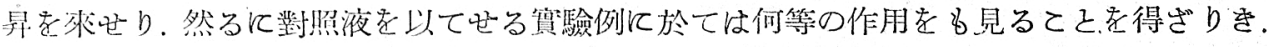

\section{C. 灌流液の墓腓腸筋灌流標本の收餗高に及ぽす影響}

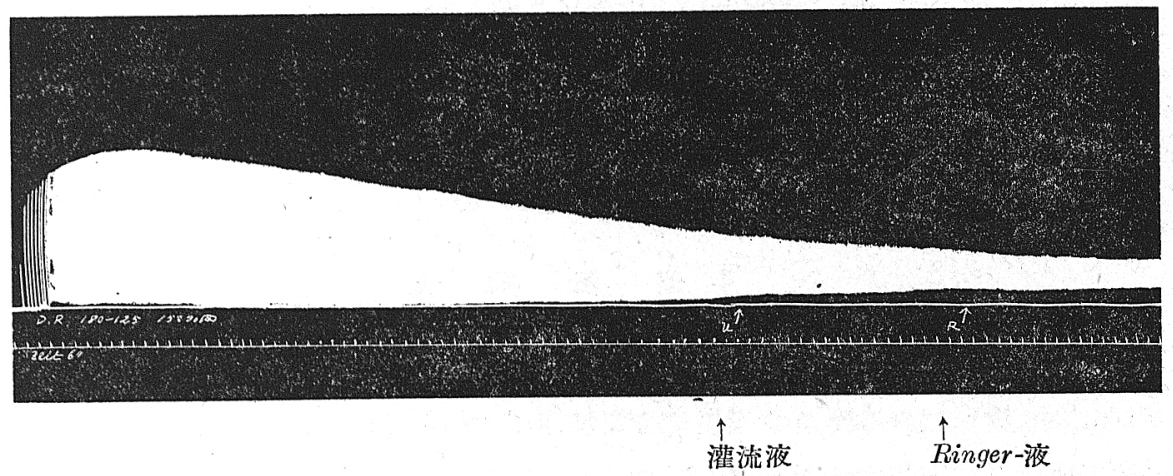

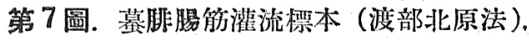


渡部，北原 ${ }^{35}$ ) の考案になる蟇腓腸筋灌流標本を作製し，之に 1)，2)，3)の方法にて 得 たる灌流液を作用せしむるに，對照例と同樣其收縮高に全く何等の影響をも認むるてとを 得さりを(第 7 圖寥照).

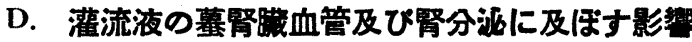

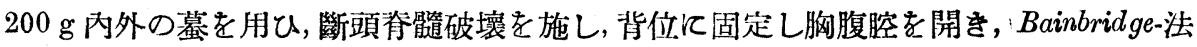
によりり蟇腎臟血管灌流標本を作製し，腎血管及び腎分泌に及注す影響を見るべく腎動脈及 び腎靜脈より正常Barkan-液を灌流し, 灌流速度及び 輸尿管端よりの人贡尿滴下液數の均 定するを待ち，是をBarkan-夜を以て捕集せる能動性物質含有の液に 轉換すれば第 12 圖の 如く腎動脈及び靜脈共に僅に擴張を示し，同時に僅に腎分泌の无進を招來するを認めたり。 對照液に於ては·Barkan-液を以て灌流するときと同樣の所見を呈するを見をり.

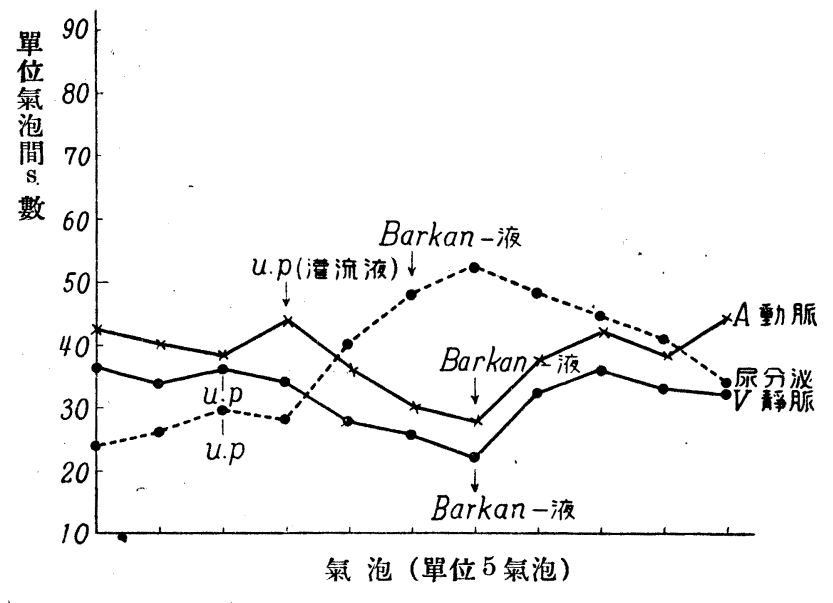

第 8 圖. 蕧腎血管及び尿分泌。

\section{E. 種々なる要約下に於ける灌流液の能動性の顡化}

前記諸實驗に於て明なる如く紫外線照射後の灌流液には藥理學的能動性物質の含有せ らるってとは明となれり。依つて該灌流液の 能動性なる物質の二, 三物理化學的性質を知 らんとして，㪈谷第三法による對剔出心藏作用を目標として本賽驗を行へり。

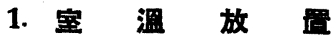

豫め被檢蟇心臟に對して促進作用あるを確めたる紫外線照射蟇の灌流液を空溫 $\left(22^{\circ}\right.$ 一 $\left.25^{\circ} \mathrm{C}\right) 飞 24^{\mathrm{h}}$ 放置したる後他の剔出蟇心臟て作用せしむるに同樣促進作用を示せり．即ち 空溫放置により該灌流液の對心臟作用は消失し居らさるを知れり（第 8 圖參照）. 


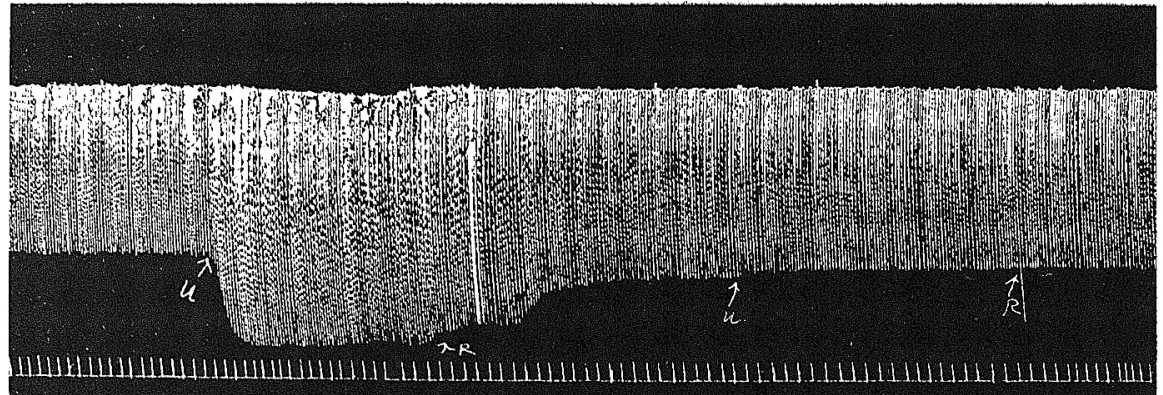

浟流液

$\stackrel{\uparrow}{\text { Ringer-液 }}$

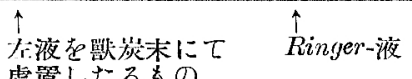

第 9 圖 (㪇谷第 3 法).

\section{2. 加熱}

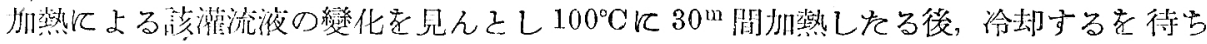

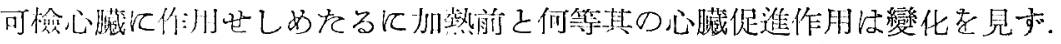

\section{3. 吸着}

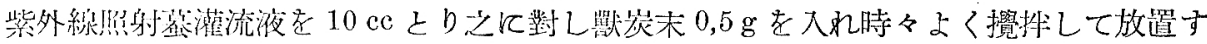

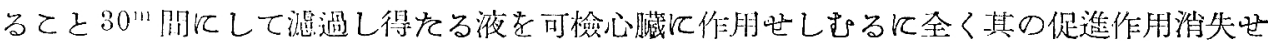

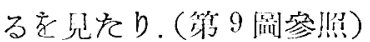

\section{4. 紫外線照射}

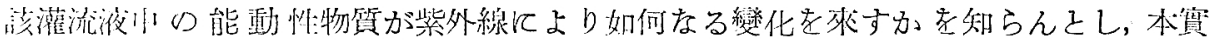

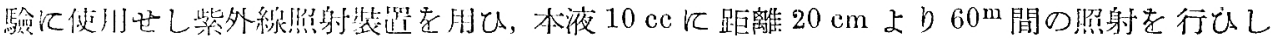

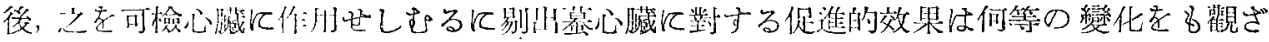
りき.

\section{5. 透 析 怪}

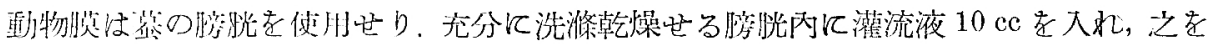

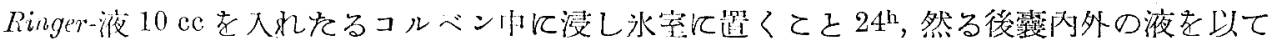

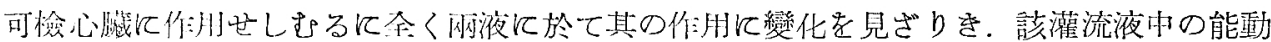
州:物饮江動物脱を透析し得るを知れり。

\section{6. 灌流波の二,三化學性狀に就て}

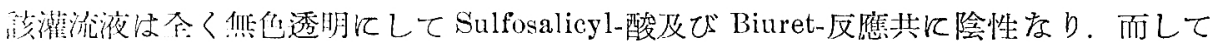

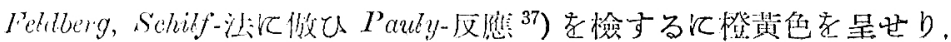


$\mathrm{pH}$ 值は灌流と使用せる Ringer-液の $\mathrm{pH}$ 值 7,4 と同值なるを觀たり.

\section{Histamin Łの異同}

以上實驗成績を通覽するに生物學的又は，理學的性質に於ては該灌流液は Histamin 又・ は.Histamin 樣物質に相似たるもの」姐し. 殊に Trendelenburg Ettingr は紫外線照射を行 ふ時, 其の照射部の皮膚䚾 Histamin の座成せらる〉を唱人, 亦岩永, 竹林, 松下, 西等当組 織又は血中に Histamin の增量せるを實驗的に明にせりと云ふ. 茲に 於て余の得たる灌流 液と Histamin 又は Histamin 樣物質との異同を明にするの要を生ぜり.

既に本敉室安野は蟇心藏に對して Histamin は䓔明なる促進作用を示し且該促進作用 は長時間に瓦りて維持せられ組織に於て解毒せられざるを明てせるる, 余の得をる灌流液 は一時强心作用を示する暫時てして其の作用減弱し遂には消失するものにして心臟組織に 於て解毒せらる〉を知れり. 又第一心藏に作用せしめたる灌流液を第二心藏に與へ作用せ しむるに明に第一心藏に於て解毒せられたるを知る。

又 Histamin は安野, 渠秋の實驗の結果によれば蟇肺臟血管に鹪張的作用を示すて反し

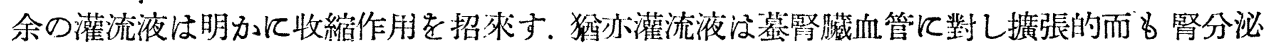
充進的に作用せり。然るに Histamin は何等の影響をも示さず之安野, 嶋田等の害驗的に明 にせる所なり。

獈Pauby-反應の色調に於ても Histamin Ringer-液は桃紅色を呈せるに本液は橙黄色を

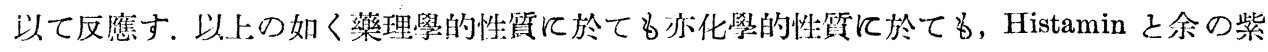
外線照射により得たる灌流液とは異なる物質なるは明なり。

\section{Histotoxin $\llcorner$ 關係}

紫外線照射幕の灌流液に含有せる能動性物質が前記の如く Histamin そは異る物質な るを明にせるにより, 余江更に本呚室の三浦, 安野, 嶋田等が理學的或は 化學的に障碍せ られたる組織より得たる Histotoxin と如何なる關係てありやを檢討せり．即ち安野, 嶋田 等の發表せる所見と余の實驗成績と全く相一致す，之を詳述すれば，即ちPauly-反應の色

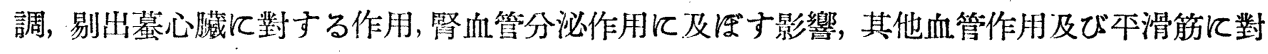
する作用等全く相一致せる結果を得をり.唒其他吸着加熱による影響及び透析性等能く余 の灌流液々 Histotxin のそれとは之また一致せり：されば安野, 上原, 沜田等の酸或はアル カリにて組織を障害し或は凍賃又は熱傷を加へて得たる能動性物質, 又は劉の Röntgen 線 照射蟇より得をる能動性物質之相一致し，紫外線照射を施せる幕の灌流液中の 能動性物質 は Histotoxin なりと謂ふを得。 


\section{VI. 家鬼血液像に對する作用}

前記實驗により紫外線紧射を行ふ時, 殊に II. 3)の實驗の結果よりして明に生體內に 能動性物質が商生せらるってとを知り得をり。亦此物質は Histotoxin と一致するものなる 事子明となれり。

做しながら唒健常動物に紫外線照射を行ふ時常に Histotôxin の産生せらるるや否やを 窥はんとして，紫外線照射墓の灌流液を家鬼に注射し血液像の 變化を檢し，一方家鬼に 紫

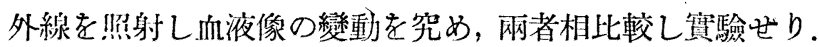

\section{A． 灌流液の家鬼血液像に及ぼす影響}

能動性物質合有の灌流液を㨫重每舮 $5,0 \mathrm{cc}$ 雄性家鬼耳款靜脈內に 注入し, 其赤血球白 血球數及び血色素量を测定し月.同時に血液叙抹標本を作製し，各種白血球百分率を 明にせ り.一方に對照としてRinger-液注入の家鬼群を作り相比較せり.

而して該對照群に於ける血液像殆んど變化なきも，灌流液注入の家鬼に於ては何れも 第 3,4 表の示せる如く白血球の漖明なる垻加を示せり. 更に各種白血球間の關係に 於ては

第3表，家鬼 血 液”像.

\begin{tabular}{|c|c|c|c|c|c|c|c|c|c|}
\hline I & $\begin{array}{l}\text { 赤血 } \\
\text { 球數 } \\
\text { (喵) }\end{array}$ & $\begin{array}{l}\text { 白 血 } \\
\text { 球 数 }\end{array}$ & $\begin{array}{c}\text { 血色素 } \\
(\%)\end{array}$ & $\begin{array}{c}\text { 大 } \\
\text { 淋巴球 } \\
(\%)\end{array}$ & $\begin{array}{c}\text { 小 } \\
\text { 淋巴球 } \\
(\%)\end{array}$ & $\begin{array}{c}\text { 墭基 嗜 } \\
\text { 好性細胞 } \\
(\%) \\
\end{array}$ & $\begin{array}{c}\text { Eosin } \\
\text { 嗜好細胞 } \\
(\%) \\
\end{array}$ & $\begin{array}{c}\text { 大單核並 } \\
\text { 移 行 型 } \\
(\%)\end{array}$ & $\begin{array}{c}\text { 假性 Eo- } \\
\text { sin 嗜好 } \\
\text { 性 細 胞 } \\
(\%)\end{array}$ \\
\hline 注 射 前 & 526 & 7200 & 75 & 13,0 & 45,0 & 3,0 & 1,0 & 3,0 & 35,0 \\
\hline
\end{tabular}

灌流液 (U) 體重每䏕 $5 \mathrm{ccm}$ 靜脈內注射 家鬼 $2200 \mathrm{gr}$. $。$

\begin{tabular}{r|r|r|r|r|r|r|r|r|r|r}
\hline & 角目 & 537 & 5200 & 73 & 24,0 & 38,0 & 3,0 & 0 & 11,0 & 24,0 \\
& $3^{\mathrm{h}}$ 目 & 516 & 9600 & 68 & 11,0 & 28,0 & 1,5 & 1,0 & 7,5 & 49,0 \\
射 & $5 \mathrm{~h}$ 目 & 528 & 14200 & 71 & 9,7 & 25,8 & 1,0 & 0 & 2,1 & 61,4 \\
& $8^{\mathrm{h}}$ 目 & 507 & 11400 & 73 & 10,7 & 36,65 & 1,0 & 0 & 0,95 & 50,7 \\
後 & $24 \mathrm{~h}$ 目 & 531 & 6800 & 76 & 14,8 & 51,1 & 0,7 & 0 & 4,6 & 29,3
\end{tabular}

第 4 表. 家 鬼 血 液 像.

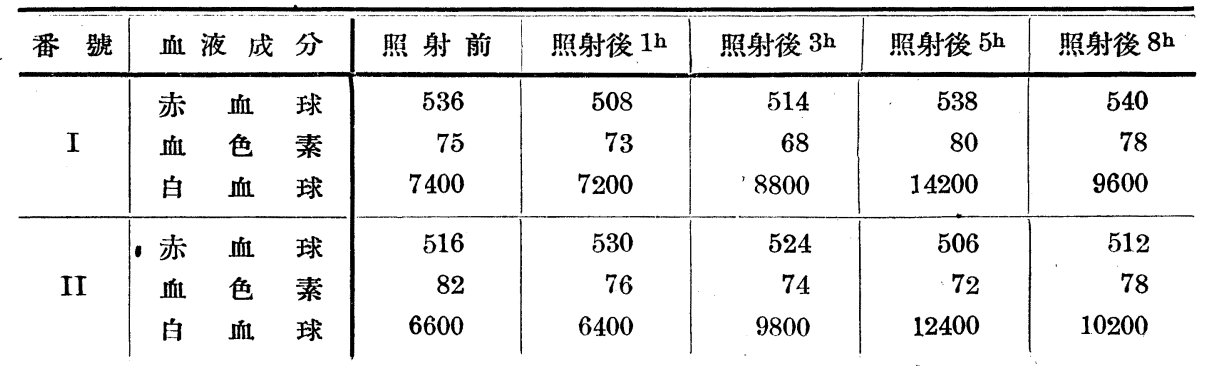




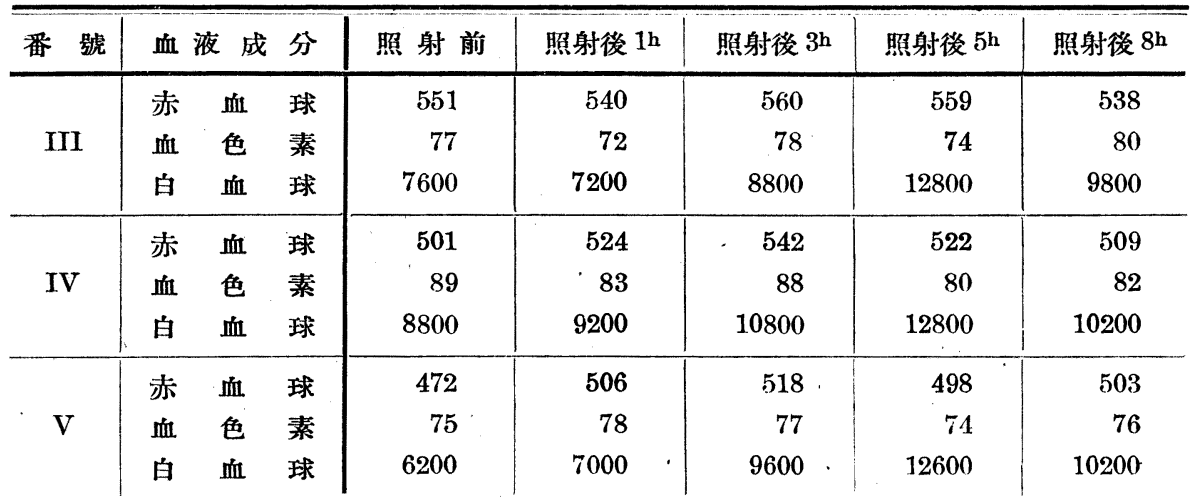

假性 Eosin 赀好性細胞の增加を來し一方淋巴球の減少を招來せり．凶みに家鬼は實驗小絶 食し，食飰に因る血液像の變動を防止せし事勿論なり。

\section{B. 紫外線照射を施せる家鬼血液像}

A. 實驗に使用せる家鬼之同樣條件下に置ける家鬼を仰臥位に固定し，恥骨縫際迄兩後 肢を照射野とし，照射距離 $20 \mathrm{~cm}$ 照射時間 $30^{\mathrm{m}}$ 間と定め，照射後 $1^{\mathrm{h}}$ 目より $8^{\mathrm{h}}$ 目迄の 血液 像の變化を精查せり，即ち第 5 表に示せる如く假性 Eosin 啫好性細胞の增多を主とせる白 血球增加を招來せり.

苐 5 表. 家 鬼 血 液 像.

\begin{tabular}{|c|c|c|c|c|c|c|c|c|c|c|}
\hline \multirow{3}{*}{ 照 射 前 } & $\begin{array}{l}\text { 赤血 } \\
\text { 球數 }\end{array}$ & 白 血 & 血色素 & 淋巴 & 小 & 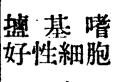 & $\begin{array}{c}\text { Eosin } \\
\text { 嗜好細胞 }\end{array}$ & $\begin{array}{l}\text { 大單核亚 } \\
\text { 移 行 型 }\end{array}$ & 假 性 Eosin & $\begin{array}{l}\text { 血色素 } \\
\text { 係 數 }\end{array}$ \\
\hline & （萬） & 球 & $(\%)$ & $(\%)$ & $(\%)$ & $(\%)$ & $(\%)$ & $(\%)$ & $(\%)$ & ( $\mathrm{Hb}$ I.) \\
\hline & 501 & 8800 & 89 & 5,4 & 38,6 & 0,2 & 0,3 & 0,2 & 55,3 & 1,68 \\
\hline
\end{tabular}

紫外線照射を施せるもの家鬼 $2300 \mathrm{gr}$. $。$

\begin{tabular}{c|c|c|r|r|r|r|r|r|r|r|r}
\hline 紫 & $1 \mathrm{~h}$ 目 & 524 & 9200 & 83 & 6,9 & 42,2 & 0,4 & 0,1 & 0,2 & 50,2 & 1,16 \\
外 & $3 \mathrm{~h}$ 目 & 542 & 10800 & 88 & 8,2 & 42,6 & 0,5 & 0,3 & 0,1 & 48,3 & 1,22 \\
線 & $5 \mathrm{~h}$ 目 & 522 & 12800 & 80 & 4,4 & 26,0 & 0 & 0 & 0 & 69,6 & 1,28 \\
後 & $8 \mathrm{~h}$ 目 & 509 & 10200 & 82 & 10,2 & 36,2 & 0,2 & 0,1 & 0,1 & 53,2 & 1,28
\end{tabular}

然るに對照例として觀察せる 5 例に於ては殆んど變化を認むるを得さりを。

\section{C. 本篇 の考案}

紫外線照射幕の灌流液を注射したる家冤に於ても亦直接紫外線を以て紧射したる家鬼 に於ても，注射後又は照射後 $3^{\mathrm{h}}$ 目より $5^{\mathrm{h}}$ 目迄で白血球の增加を來ぜ．即ち本編 $\mathrm{A}, \mathrm{B} の$ 
實驗て於ける血液像の變化は略く相一致する現象なるを知り得たり.

即紫外線潐射後に表はるる血液像の變化の原因に對し解決を齊し得たるるのと思惟せ らるるものにして，紫外線照射幕の灌流液中に含有する能動性物質と同性質を有する物質 が紫外線照射を施したる家象の體內に生じ，その物質が造血藏器を刺钱し以て 前述の如き 家鬼の血液像の變化を惹起せしるのと推测すべきなり。されば余は紫外線照射に際し大澤 敎授提唱のHistotoxin が生成せらるよものなるを知ると同時に此の Histotoxin が血液像の 變化を惹起せる゙ものと思惟す。

\section{VII. 總括考按並に結論，}

\section{1. 總括 及び考按}

以上數編に亘りて記述したる賽驗成績を總括考案するに, 蟇に於て其後肢及び 腹部の 皮膚に紫外線照射を行ひ，其後肢血管及び 胃腸血管の灌流液を捕集し其の作用を檢せる に, 本液は一定の藥理學的成分を有し, 其の化學的性質飞於ても, 本物質は本呚空の安野が 濃厚なるアルカリ劑を用ひ, 組織を障碍したる蟇の灌流液, 三浦の火傷毒, 島田の凍賃毒な る藥理學的能動性物質即ち Histotoxin 之相一致するを知れり. 即ち剔出暮心臟に對して促 進的に作用し且心臟組織によりて解毒せらる.家鬼血壓に對しては僅に一時下降を示し，血 管に對しては家鬼耳款血管, 幕後肢血管, 肺藏血管及び家鬼冠狀血管て對し、何れも收縮的 て作用し, 慕腸間膜血管に對しては多少擴張的て作用す。

更に該液の平滑笳に對する作用を見るに剔出家兔腸管, 剔出家鬼子宮, 剔出蟇胃は何れ も何等の影響をも蒙らず, 只僅に剔出墓腸管が緊張下降を示せるのみ. 然るに蟇膀胱に對 しては體內剔出何れの狀態に於て作用せしむるも著明なる緊張上景学來せり。

渡部, 北原の考案に從ひ墓腓腸筋血管灌流標本を作製し之に作用せしむるに其の收縮 高には特別なる變化を招來せず.

蟇腎臟血管に該灌流液を作用せしむるに腎動脈及び腎靜脈共に輕度の擴張を示し, 而 る人工尿形成を促進せしさ該灌流液は家鬼血液像に對しては著明なる白血球殊に假性 Eosin 啫好性細胞の堤加を惹起せしめ，反對に淋巴球の減少を招來するを知れり．

本灌流液はPauly-反應橙黃色の色調を示しBiuret 反應陰性を呈し, 且 Jaffe-法䢸び Wehyl-法によりKreatin 及び Kreatinin 反應亦㓌性の結果を示せり. 是に依りて本液は蛋 白質そのものにあらさるてとは明なり。

唒本灌流液の $\mathrm{pH}$ 值は Ringer-液の $\mathrm{pH}$ 值と相同じく，即ち藥理學的能動性物質混入《 よりてもRinger-液の $\mathrm{pH}$ 值の變動を來さら゙るを知れり．

該灌流液は室溫に放道するも加熱するも唒紫外線照射を加へるも其の效力の減退を招 
來せず. 然るに本物質は吸着劑にて吸着され且動物膜に對し透析性を估せり。

Trendelenburg，Eltinger，岩永，竹林，松下. 西等の見解に依れば紫外線照射を施せる部の 皮膚組織又は血中に Histamin が產成せられ之が作用機轉に干與すと說明せるも，䂗述の 如くHistamin と相一致せざる點多し.

他方本教室の劉が Röntgen 線照射䓨を灌流し得たる能動性物質が Histotoxin と同… 性質を有し，且余つ紫外線照射幕を灌流して得たる能動性物質と全く相一致するを觀るに 及び Trendelenburg, Etlinger 等の紫外線作用機轉の說明には疑義深きものありとの感老起さ しむ. 余は寧ろ本能動性物質が紫外線作用機轉の主役をなするのなりを思惟す。即ち Histotoxinは紫外線を以て組織を照射する時て於てb產成せらる」ものにして, 其の Histotoxin

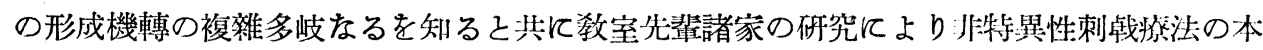
態は Histotoxinの作用によるものなる事を明にせられたるにより紫外線照射の如きる一つ

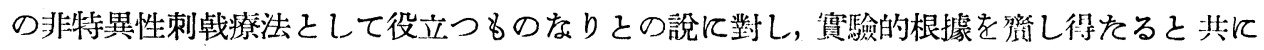

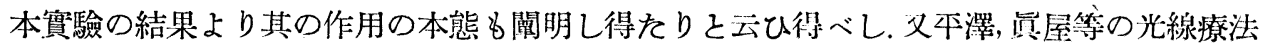
を廣義の刺戱療法なりと唱ふる見解も亦宜なりと謂ふべし。

\section{2. 結 論}

以上の賽驗成績よりして余は次の如き結論に達するてとを得たり．

1. 慕後肢を灌流しつ小紫外線照射を行ふ時又は紫外線照射を施し, 然る後に後肢血 管又は胃腸血管を灌流する時其の灌流液飞藥理學的能動性物質の出現するを知れり。

2. 該物質含有の灌流液は Pauly-反應に對して, 橙黄色の色調を以て反應す.

3. 慕血管に作用せしむる時は胃腸血管を搌張し, 後肢血管”, 肺臟血管を收縮せしむ。

4. 家鬼の冠狀血管耳款血管を收繀し、僅に血壓を下降せしめ, 其の血液像に對し 假性 Eosin-嗜好性細胞增多を主とせる白血球增多症を招來す。

5. 平滑筋に對する作用を觀るに剔出䓪腸管に對し僅に緊張下降的に作用するのみに

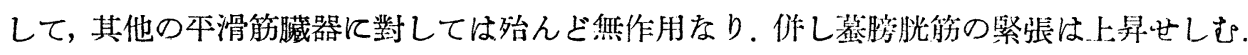

6. 慕腎臟機能を元進せしむ。

7. 耐熱性にして動物膜透析性を有す。

8. Histamin とは生物學的作用に於て異り Histotoxin とは相一致せり。

6. 紫外線照射に依りて Histotoxin の產成せらるっを知れり。

10. Histotoxin が紫外線作用機轉の主役をなすものなり.

擱筆するに裳り恩師大澤教授及び上田助教授の御指導及び御校閂を深謝する。 


\section{引用 書 目}

1) Hertel: Zt. f. allgem. Phy. 5, 535 (1905).

2) Schleip: Arch. f. Zellforschung 17, 289 (1923).

3) 小野：金澤頤科大學十全會雜誌 34, 667 (昭和 4 年).

4) Gassut: •Deutsch. med. Wochenschr. 22, 918 (1923).

5) Levy: Strahlentherapie. 18, 681 (1924).

6) Nathan: 岩永より引用.

7) Sack：岩永より引用.

8) T'rendelenburg: Arch. f. exp. Path. u. Pharm. 136, 129 (1928).

9) Ellinger: Ebenda. 136, 129 (1928).

10) 岩 永：大阪醫事新誌 $4,580,720$ (昭和 8 年).

11）竹林：大阪醫事新誌 $887,1012,1182,1322$ (昭和 8 年).

12) 松下：日本病理學會會誌 23, 789 (昭和 8 年).

13）西：日本放線醫學會稚誌 2,441, 及び 445 (昭和 9 年).

14) 小池: 結 核, 1927, 7, 656 (1927).

15) 金倉：結核, 1927, 7, 656 (1927).

16) 上坂: 結 核, 1927, 7, 656 (1627).

17) 大里：日本內科學會雜誌 15, 343 (昭和 2 年).

18）田中：日本內科學會雜誌 15, 343 (昭和 2 年).

19) Seyperhelm: Klin. Wochenschrift, 1932, Jg. 11. Nr, 15, S. 628. J. Amer. Med. Asoc. 80, 687 (1923).

20) Hess: Klin. Wochenschrift, 1932, Jg. 11. Nr, 15, S. 628. J. Amer. Med. Asoc 80, 687 (1923).

21) Weinstock: Klin. Wochenschrift, 1932, Jg. 11. Nr, 15, S. 628. J. Amer Med. Asoc. 80, 687 (1923).

22)Windaus: Proc. of the. Soc. of Experim. Bial. and Medicine. 24, 461, 462 (1924).

23) Sorgo: The Britisch Journal of Actiatherapy and Physiotherapy. 5, 149 (1230).

24) Bernhard: Sogo, The Britisch Journal of Actiotherapy and Physiotherapy (1930).

25) Hausmann: Meyers Lehrbnch der Strahlentherapre, 1 (1925).

26) 平等：結核：10（昭和 7 年).

27）眞屋：金澤醫科大學一个全會雜誌 39, （昭和 9 年）；39，（昭和 9 年）；40，（昭和 10 年）

28) 劉：日本レントゲン學會雜誌 16. 193 (昭和 13 年).

29) 三浦： 東京醫學會稚誌 46, 413 (昭和 7 年).

30) 安野：東京醫學會䨀誌 49, 1564 (昭和 10 年).

31) 嶋田：東京㼟學會稚誌 49, 1130 (昭和 10 年).

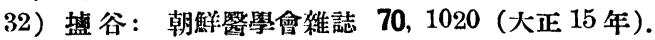

33 ) 上田韓：第 12 回日本藥理學會記事 4 (昭和 13 年).

34) 大澤：朝然㹂學會雜誌 52,65 (大正 13 年).

35 ) 渡部, 北原：朝鮮學學會雜誌 20,829 (昭和 5 年).

36) Bainbridge: Journ.Physioloyie. 53, 233 (1923).

37) Pauly: Zit. n. Feldherg W. E Sehied; (Julius Springer) 16 (1930). 
wicht beobachtet man auf die anfängliche Leucopenie folgende Vermehrung der pseudoeosinophilen Leucocyten, welche im Laufe von 5 Stunden das Maximum erreicht. Diese Erscheinungen werden durch kombinierte Anwendung dieser beiden Substanzen deutlich verstärkt. [Vgl. Original (japanisch) S. 323.]

(Autoreferat.)

Beiträge zur Kenntnis des Histotoxins.

I. Über die Histotoxinbildung bei der Bestrahlung mit ultravioletten Strahlen.

\section{Von}

\section{Koma Nakahashi.}

Aus dem Pharmakologischen Institut der Kaiserlichen Universität Keijo.

(Vorstand: Prof. Dr. Masaru Osawa.)

Eingegangen am 29. Juni 1942.

Experimentelle Untersuchungen über die Behandlung mit ultravioletten Strahlen sind bereits von vielen Autoren ausgeführt worden, doch bleibt das Heilwesen dieser Therapie noch. ungeklärt. In der vorliegenden Arbeit habe ich mich bemüht, dieses Heilwesen klarzulegen. Meine Untersuchungen wurden in folgender Weise angestellt.

Methodisches: Als Versuchstiere wurden .japanische sowie koreanische Kröten von ungefähr $200 \mathrm{~g}$ Körpergewicht verwendet. A) Das Hinterbein der Kröte wurde nach Laewen-Trendelenburgscher Methode fortlaufend mit Ringerscher Lösung durchströmt. Nachdem das Perfusat keine Eiweissreaktion gegen Sulfosalicylsäure mehr zeigte, wurde es als Kontrollfüssigkeit gesammelt. Dann wurde die Durchströmung unterbrochen, das Hinterbein wurde eine bestimmte Zeit lang mit ultravioletten Strahlen bestrahlt, und dann wurde wieder das Perfusat gesammelt. B) In gleicher Weise bestrahlte man mit ultravioletten Strahlen den Bauch sowie die Hinterbeine der Kröte, an welcher die Mesenterialsowie Schenkelgefässe durchströmt wurden, und das dabei gewonnene Perfusat wurde $\mathrm{zu}$ den weiteren Versuchen verwenden.

Bestrahlungsmethode: Apparat analytische Lampe von Shimazu, Type A. Volt 100, MA. 6, Wellenlänge 316--360 mm.

Bestrahlungsabstand

Bestrahlungsdauer

Zahl der Bestrahlungen

Bestrahlungsort
$20 \mathrm{~cm}$

5 bis 30 Minuten

bei A) $1 \mathrm{mal}$, bei B) $1-3 \mathrm{mal}$

Unterleib und Bauchseite des Hinterbeins

Bei diesen Versuchen konnten die folgenden Ergebnisse festgestellt werden: 
Das Perfusat reagiert auf die Paulysche Reaktion mit Orangegelb, wie Histotoxin. Auf den Blutdruck des Kaninchens übt das Perfusat stets eine kurzdauernde senkende Wirkung aus. Auf die künstlich nach der III. Methode von Shioya gespeisten Krötenherzen wirkt es stets anregend und wird durch Herzgewebe entgiftet. Ferner wirkt es kontrahierend auf verschiedene Gefässe der Kröte mit Ausnahme der Mesenterial- sowie der Nierengefässe. Die Sekretion der Krötenniere kann durch die Perfusatapplikation ebenfalls gefördert werden. Das Perfusat übt auf den Darm und den nicht trächtigen Uterus des Kaninchens sowie den Magen der Kröte keine fördernde Wirkung aus.

Am Krötendarm zeigt es eine hemmende Wirkung. Dagegen sieht man sowohl an der in situ befindlichen, als auch an der isolierten Blase der Kröte eine Tonussteigerung. Das Perfusat übt keine merkliche Wirkung auf die nach der Watanabe-Kitaharaschen Methode durchströmten Gastrocnemien der Kröte aus. Das Perfusat ruft im Verlauf von 3-5 Stunden nach der Injektion an Kaninchen Leukocytose hervor, welche hauptsächlich der Vermehrung der pseudoeosinophilen Zellen zuzuschreiben ist. Die Wirksamkeit 'dieses Perfusates geht weder durch 24 stündiges Stehenlassen bei Zimmertemperatur, noch durch ein stündige Bestrahlung mit Ultraviolettstrahlen noch auch durch halbstündiges Erhitzen auf $100^{\circ} \mathrm{C}$ verloren, ferner ist es leicht dialysabel. Die aktive Substanz wird auch durch Tierkohle adsorbiert. Dieser aktive Stoff unterscheidet sich pharmakologisch vom Histamin ; denn Histamin wirkt nie diuretisch auf die Krötenniere, und kontrahierend auf die Nierengefässe der Kröte. Wéiter wird das Histamin durch das Krötenherz nicht entgiftet. Auf die Paulysche Reaktion zeigt Histaminlösung rote Färbung. Aus diesen Ergebnissen lässt sich schliessen, dass die Pharmakoaktivität des Perfusates des mit urtlavioletten Strahlen bestrahlten Gewebes dem Histotoxin zuzuschreiben ist. Zugleich möchte ich behaupten, dass das Moment, welches bei Ultraviolettbestrahlung die Hauptrolle spielt, nichts anders als die WWirkung des Histotoxins ist. [ $\mathrm{ggl}$. Original (japanisch) S. 336.]

(Autoreferat)

\section{The Effect of Various Derivatives of Sulfonamide on Tissue Culture.}

By

\section{Dr. Shunzo Satomura.}

From the Pharmacological Institute of the Kyoto Imperial University.

(Director: Prof. Dr. Y. Ozaki and Prof. Dr. K. Ogiu.) Received" for publication July 1st, 1942. 